\title{
Dopaminergic Neurotransmission in Patients With Parkinson's Disease and Impulse Control Disorders: A Systematic Review and Meta-Analysis of PET and SPECT Studies
}

\author{
Alice Martini ${ }^{1 *}$, Denise Dal Lago ${ }^{1}$, Nicola M. J. Edelstyn ${ }^{1}$, Matteo Salgarello $^{2}$, \\ Fabio Lugoboni ${ }^{3}$ and Stefano Tamburin ${ }^{4}$ \\ ${ }^{1}$ School of Psychology, Keele University, Newcastle-under-Lyme, United Kingdom, ${ }^{2}$ Department of Nuclear Medicine, \\ Ospedale Sacro Cuore Don Calabria, Verona, Italy, ${ }^{3}$ Addiction Unit, Department of Internal Medicine, University Hospital of \\ Verona, Verona, Italy, ${ }^{4}$ Department of Neurosciences, Biomedicine and Movement Sciences, University of Verona, Verona, \\ Italy
}

OPEN ACCESS

Edited by:

Mayela Rodríguez-Violante, Instituto Nacional de Neurología y

Neurocirugía (INNN), Mexico

Reviewed by:

T. Celeste Napier,

Rush University, United States

Graziella Madeo,

National Institutes of Health (NIH),

United States

${ }^{*}$ Correspondence:

Alice Martini

alice.martini.2@gmail.com

Specialty section

This article was submitted to

Movement Disorders,

a section of the journal

Frontiers in Neurology

Received: 26 July 2018 Accepted: 12 November 2018 Published: 04 December 2018

Citation:

Martini A, Dal Lago D, Edelstyn NMJ,

Salgarello M, Lugoboni F and

Tamburin S (2018) Dopaminergic Neurotransmission in Patients With

Parkinson's Disease and Impulse

Control Disorders: A Systematic Review and Meta-Analysis of PET and

SPECT Studies.

Front. Neurol. 9:1018. doi: 10.3389/fneur.2018.01018
Background: Around 30\% Parkinson's disease (PD) patients develop impulse control disorders (ICDs) to $D_{2 / 3}$ dopamine agonists and, to a lesser extent, levodopa. We aim to investigate striatal dopaminergic function in PD patients with and without ICD.

Methods: PubMed, Science Direct, EBSCO, and ISI Web of Science databases were searched (from inception to March 7, 2018) to identify PET or SPECT studies reporting striatal dopaminergic function in PD patients with ICD (ICD+) compared to those without ICD (ICD-). Studies which included drug naïve patients, explored non-pharmacological procedures (e.g., deep brain stimulation), and those using brain blood perfusion or non-dopaminergic markers were excluded. Standardized mean difference (SDM) was used and random-effect models were applied. Separate meta-analyses were performed for dopamine transporter level, dopamine release, and dopamine receptors availability in the putamen, caudate, dorsal, and ventral striatum.

Results: A total of 238 studies were title and abstract screened, of which 19 full-texts were assessed. Nine studies (ICD+: $N=117$; ICD-: $N=175$ patients) were included in the analysis. ICD+ showed a significant reduction of dopamine transporter binding in the putamen (SDM $=-0.46 ; 95 \% \mathrm{Cl}:-0.80,-0.11 ; Z=2.61 ; p=0.009)$, caudate $(\mathrm{SDM}=-0.38 ; 95 \% \mathrm{Cl}:-0.73,-0.04 ; Z=2.18 ; p=0.03)$ and dorsal striatum (SDM = $-0.45 ; 95 \% \mathrm{Cl}:-0.77,-0.13 ; Z=2.76 ; p=0.006)$, and increased dopamine release to reward-related stimuli/gambling tasks in the ventral striatum (SDM $=-1.04 ; 95 \%$ Cl: $-1.73,-0.35 ; Z=2.95 ; p=0.003$ ). Dopamine receptors availability did not differ between groups. Heterogeneity was low for dopamine transporter in the dorsal striatum $\left(l^{2}=0 \%\right)$, putamen $\left(l^{2}=0 \%\right)$ and caudate $\left(l^{2}=0 \%\right)$, and pre-synaptic dopamine release in the dorsal $\left(I^{2}=0 \%\right)$ and ventral striatum $\left(I^{2}=0 \%\right)$; heterogeneity was high for dopamine transporter levels in the ventral striatum $\left(l^{2}=80 \%\right)$, and for dopamine receptors availability in the ventral $\left(l^{2}=89 \%\right)$ and dorsal $\left(I^{2}=86 \%\right)$ striatum, putamen $\left(l^{2}=93 \%\right)$, and caudate $\left(l^{2}=71 \%\right)$. 
Conclusions: $I C D+$ patients show lower dopaminergic transporter levels in the dorsal striatum and increased dopamine release in the ventral striatum when engaged in rewardrelated stimuli/gambling tasks. This dopaminergic imbalance might represent a biological substrate for ICD in PD. Adequately powered longitudinal studies with drug naïve patients are needed to understand whether these changes may represent biomarkers of premorbid vulnerability to ICD.

Keywords: Parkinson's disease, impulse control disorder, dopamine, PET, SPECT, transporter, receptors, metaanalysis

\section{INTRODUCTION}

Impulse control disorders (ICD), such as pathological gambling, hypersexuality, binge-eating, and compulsive shopping are diagnosed in around $30 \%$ of patients with Parkinson's disease (PD) (1-4).

ICDs are considered a complication of $\mathrm{D}_{2 / 3}$ dopamine agonist treatment and, to a lesser extent, levodopa (5). This is evident from studies showing higher ICD rates in medicated PD patients compared to healthy controls $(2,3,6,7)$. Although ICD rates have not been directly compared between medicated and drug naïve PD patients, other studies have shown that rates in drug naïve PD patients do not differ from healthy controls $(8,9)$. There are also retrospective case reports (10-12) and prospective studies (13-15) showing that in some cases ICDs onset (10$12,14,15)$ and their reduction or resolution $(10,13,16)$ covary with dopaminergic treatment.

Preclinical animal studies provide further evidence of a modulatory effect of dopamine agonists on impulsivity using delay discounting paradigms. In these paradigms, impulsivity results in a behavioral preference for an immediate (smaller) reward over a delayed (larger) reward. However, the direction of the effect of dopamine on the reward system is inconsistent. For example, some studies showed lower levels of impulsivity on 1 and $2 \mathrm{mg} / \mathrm{kg}$ doses of $d$-amphetamine $(17,18)$ whereas others report increased impulsivity in rats treated with similar or higher doses (e.g., $0.8,1,1.20,3.2 \mathrm{mg} / \mathrm{kg})(19-21)$ or no effects $(21,22)$.

Studies in healthy volunteers show a modulatory effect of dopamine agonists on impulsivity; however, like rodent studies previously mentioned, the direction of the effect is unclear, in that some studies report increased impulsivity while other ones show decreased impulsivity to dopamine agonists. For example, $d$-amphetamine decreases impulsive behavior on the Stop task and in the Go/no Go task (measured as Stop reaction time and number of false alarms), and decreases delay discounting (23). However, other dopaminergic agents such as levodopa and pramipexole increase impulsivity on delay discounting and gambling tasks $(24,25)$.

In summary, evidence from preclinical rodent studies and healthy volunteers indicate that dopamine agonists modulate the reward system and impulsivity, but the direction of the effect is not clear. This implies that impulsivity is modulated by a complex interplay of dopamine activity across a network of systems, and dopamine agonists disrupt the balance between brain areas modulating impulsivity.
In the first stages of $\mathrm{PD}$, the function of ventral striatum is relatively more preserved than the dorsal striatum (26). Therefore, the dopaminergic treatment dose required to restore motor dorsal striatal dopaminergic levels may overstimulate the relatively intact ventral striatum (27). This hyperdopaminergic state may promote an abnormal activity in the connected corticostriatal cognitive and limbic pathways that mediate rewardrelated behavior (28). As a consequence, the control of goaldirected behavior is impaired, facilitating ICD development.

If ICDs in PD are linked to the disruption of the equilibrium in dopamine activity across ventral and dorsal striatum, then brain positron emission tomography (PET) and single-photon emission computed tomography (SPECT) can provide a direct measurement of putative dopaminergic differences between PD with and without ICDs. These nuclear medicine techniques use molecular imaging to assess biochemical, neurochemical, or pharmacological processes in the brain. For example, changes in neurotransmission can be detected using radiotracers with high affinity for dopamine receptors.

When a radiotracer is injected, it competes with dopamine for binding to free dopamine receptors. Thus, if dopamine is released endogenously, radiotracer binding can therefore be used as a marker for dopamine release (29). According to the binding affinity and the type of radiotracer, it is possible to investigate the nature of the dopaminergic dysfunction, whether linked to dopamine release, dopaminergic re-uptake in the presynaptic terminals, and $\mathrm{D}_{2 / 3}$ post-synaptic receptors availability. The spatial resolution of current PET and SPECT machines allow separate assessment of the dorsal and ventral striatal regions, and their components (i.e., putamen, caudate).

A limitation of the PET and SPECT studies of ICD in PD published so far is the small sample size, with the largest study including 21 PD patients with ICD and 68 without ICD (30) and the smallest including 7 PD patients with ICD and 7 without ICD (31). Small sample sizes are not surprising, given the high cost of PET and SPECT exams. Moreover, variability in clinical and demographic characteristics, types of tracer, protocols of analysis, and scanners makes the comparison between studies difficult.

A meta-analytic approach can overcome these limitations. Low powered studies can be combined and differences in striatal dopaminergic function between PD patients with and without ICD estimated with a higher reliability. To the best of our knowledge, no previous meta-analysis has been published on this topic. 
Therefore, the objective of this study was to investigate differences in dopaminergic function in the striatum in PD patients with and without ICD. To this aim, we systematically reviewed and meta-analyzed PET and SPECT based reports on dopamine transporter level, presynaptic dopamine release, and post-synaptic $\mathrm{D}_{2 / 3}$ receptors availability in the ventral and dorsal striatum.

\section{MATERIALS AND METHODS}

\section{Search Strategy}

The PubMed, Science Direct, EBSCO, and ISI Web of Science databases were searched for peer-reviewed studies on PET or SPECT striatal dopaminergic function in PD-related ICD and published from database inception until the 7th of March 2018.

The following search string was used: "[(Parkinson's disease OR Parkinson) AND (impulse control disorders OR impulse control disorder OR impulsive compulsive behaviors $\mathrm{OR}$ impulsive compulsive behaviors OR impulsive compulsive behavior OR impulsive compulsive behavior OR ICD OR ICB OR hypersexuality OR gambling OR buying OR shopping OR eating)] AND (Positron emission tomography OR PET OR Single Photon Emission Computed Tomography OR SPECT OR SPET OR DaTSCAN)." A total of 384 papers were identified. After the exclusion of duplicates, 238 papers went through title and abstract screening. Two authors (AM, DDL) independently screened titles and abstracts using Rayyan software (32) and 17 papers were included in the full-text screening. The reference lists of these papers were manually searched for additional studies missed in the databases search, and two relevant papers were included at this stage. Two authors (AM, DDL) independently evaluated the 19 papers selected for full-text examination and disagreements were planned to be resolved via discussion with a third author (ST). However, there was 100\% agreement between the two authors. Nine studies were included for quantitative analysis (Figure 1).

\section{Selection Criteria}

Studies were included if they met the following inclusion criteria: (i) PET or SPECT study; (ii) PD patients without ICD (ICD-) compared with PD patients with ICD (ICD+); (iii) data reported for at least one striatal region; (iv) independence of the sample. Therefore, if a study sample was reported in multiple publications, only the study with the largest sample was included.

We excluded reviews, case studies, commentaries, letters, abstracts and dissertations, conference papers, and postal surveys. Studies including drug naïve PD patients were excluded, as we were interested on ICD developed after dopamine replacement treatment (DRT) initiation. Moreover, drug naïve PD patients represent a different sample than those treated with DRT, as the former have shorter PD duration, and are not chronically exposed to DRT. Therefore, dopaminergic systems may be affected and stimulated differently in medicated and non-medicated PD patients.

Studies in which PD patients underwent deep brain stimulation (DBS) were also excluded, as ICDs may either improve or develop after DBS (33). Finally, studies using measures of brain blood perfusion were excluded, as they do not explore striatal dopaminergic functioning. Similarly, we excluded studies with non-dopaminergic markers.

\section{Data Extraction}

Corresponding authors of four studies (30, 34-36) were contacted for exact data. Data reported as median and range (37) were converted to mean and SD, as proposed by Hozo et al. (38). When standard error was reported, it was converted to SD $(31,39)$. Two authors (AM, DDL) independently extracted the following demographic and clinical data: sample size, sex, age at evaluation, age at PD onset, PD duration, education (years), Hoehn and Yahr (H\&Y) stage, Unified PD Rating Scale motor section (UPDRS-III) ON-medication, depression, antidepressant use, antipsychotic use, number of patients under dopamine agonist treatment, dopamine agonist levodopa equivalent daily dose (LEDD, mg), levodopa LEDD, total LEDD, ICD screening tool, and ICD type. Methodological characteristics of the included studies were also extracted: imaging technique (i.e., PET or SPECT), type of tracer, reference region, imaging approach, radiotracer delivery method, drug delivered prior to scan, outcome measure, and striatal division and subdivision that was examined (i.e., ventral striatum, dorsal striatum, putamen, caudate).

The outcomes measures were the differences in the dopaminergic imaging parameters (e.g., binding potentials) between PD patients with and without ICD in striatal areas (i.e., ventral striatum, dorsal striatum, putamen, caudate).

\section{Data Analysis}

Separate meta-analyses were performed for studies focusing on dopamine transporter level, dopamine release (presynaptic), and dopamine receptors availability (postsynaptic) in the ventral striatum, dorsal striatum, putamen, and caudate. Data were analyzed using ReviewManager v5.3 (40). Standardized mean difference (SMD) was used as effect size measure, with values around $0.2,0.5$, and 0.8 considered as small, moderate, and large, respectively (41). Heterogeneity between studies was calculated by the $I^{2}$ value with percentages around 25, 50, and 75 considered as low, moderate, and high, respectively (42). As PD samples may vary in their clinical (e.g., H\&Y stage, UPDRS scores) and demographic characteristics (e.g., age, sex), a random-effect model was applied.

Sensitivity analysis was performed by excluding studies clearly stating current antipsychotic or antidepressant use, as these drugs may affect dopamine receptor binding potential (43) or DAT uptake (44). As the number of studies was low, we lacked the power for conducting moderator analysis (45), or visual inspections of funnel plots for publication bias (46). A $p<0.05$ was used as statistical significance threshold for all the analyses.

\section{RESULTS}

Demographic, clinical and methodological characteristics of the 117 ICD + and 175 ICD- PD patients reported in the nine studies included in the meta-analysis are reported in Tables $\mathbf{1}, 2$. 


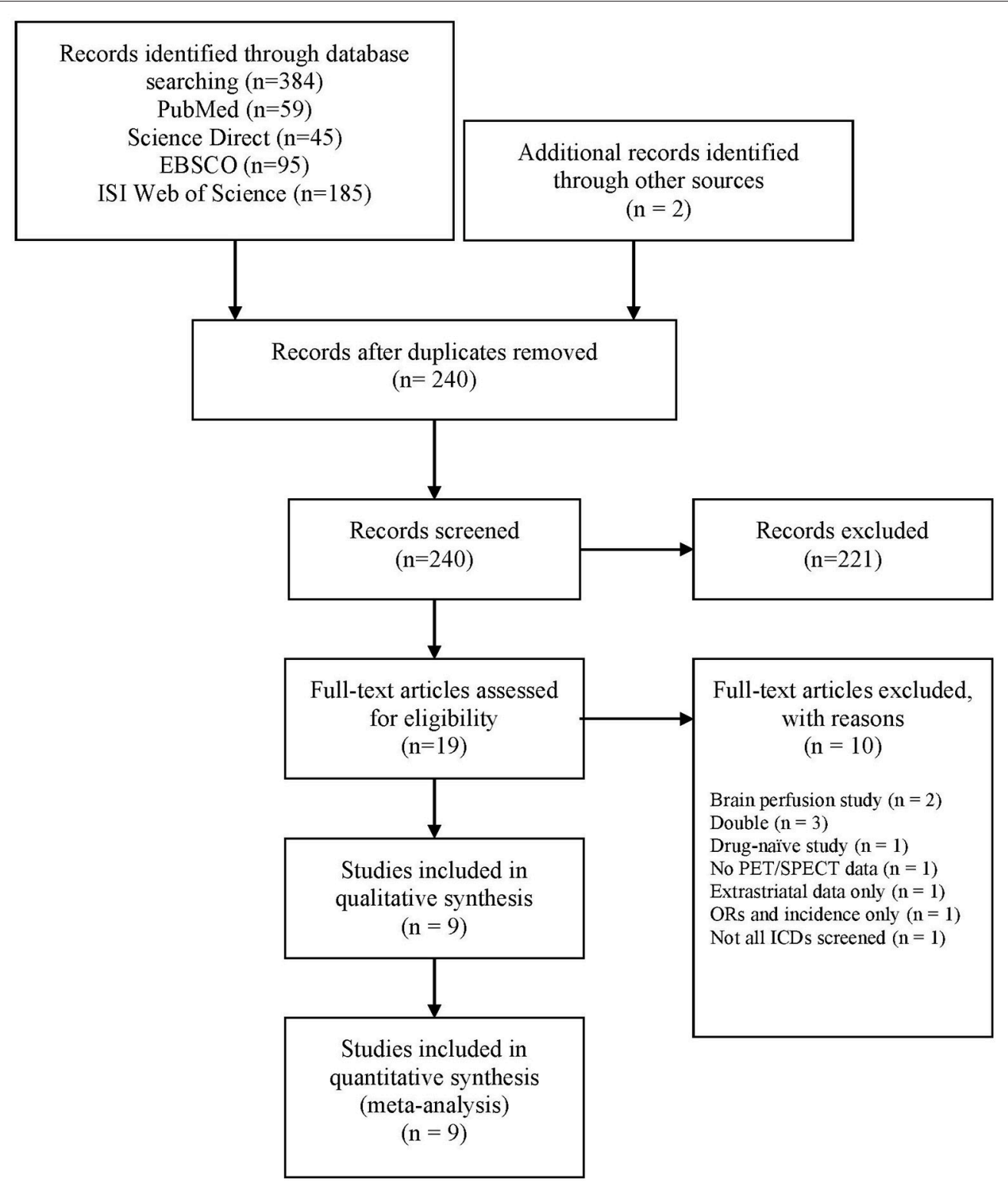

FIGURE 1 | PRISMA diagram of the study (www.prisma-statement.org). ICD, impulse control disorder; ORs, odds ratios; PET, positron emission tomography; SPECT, single-photon emission computed tomography.

There was heterogeneity on the procedure to assess ICD across studies. ICDs were diagnosed either with a clinical interview based on the Diagnostic and Statistical Manual of Mental Disorders fourth edition text revision (DSM-IV-TR) (34-37, 44, 48), the Diagnostic and Statistical Manual of Mental Disorders fifth edition (DSM 5) (39) criteria or with the Questionnaire for Impulsive-Compulsive Disorders in PD-Rating Scale (QUIP-rs) (30). In four studies, the clinical interview followed the South Oaks gambling screen (SOGS) $(34,35)$, Gambling Symptom Assessment Scale (G-SAS) (31), QUIP-rs (36), and Sexual Addiction Screening test (35). In the paper of Steeves et al. (31), no specific information was provided on criteria for diagnosing ICDs apart from the use of SOGS for pathological gambling.
All patients were under DRT. In seven studies there were no between-group differences in total or dopamine agonist LEDD $(31,34,36,37,39,44,48)$. One study reported a higher number of patients under dopamine agonist, however total LEDD and dopamine agonist doses were comparable between ICD + and ICD - groups (30). In one study ICD + had higher levodopa LEDD than ICD- (35).

One study divided the ICD+ group in single and multiple ICD subgroups (39). As the comparison between single and multiple ICD was not relevant for our meta-analysis, means and SDs of the subgroups were merged by calculating the pooled means and SDs.

Six studies provided results in the left/right $(30,34,37,39,44$, 48 ) and/or anterior/posterior striatal sub-regions (37); data from 


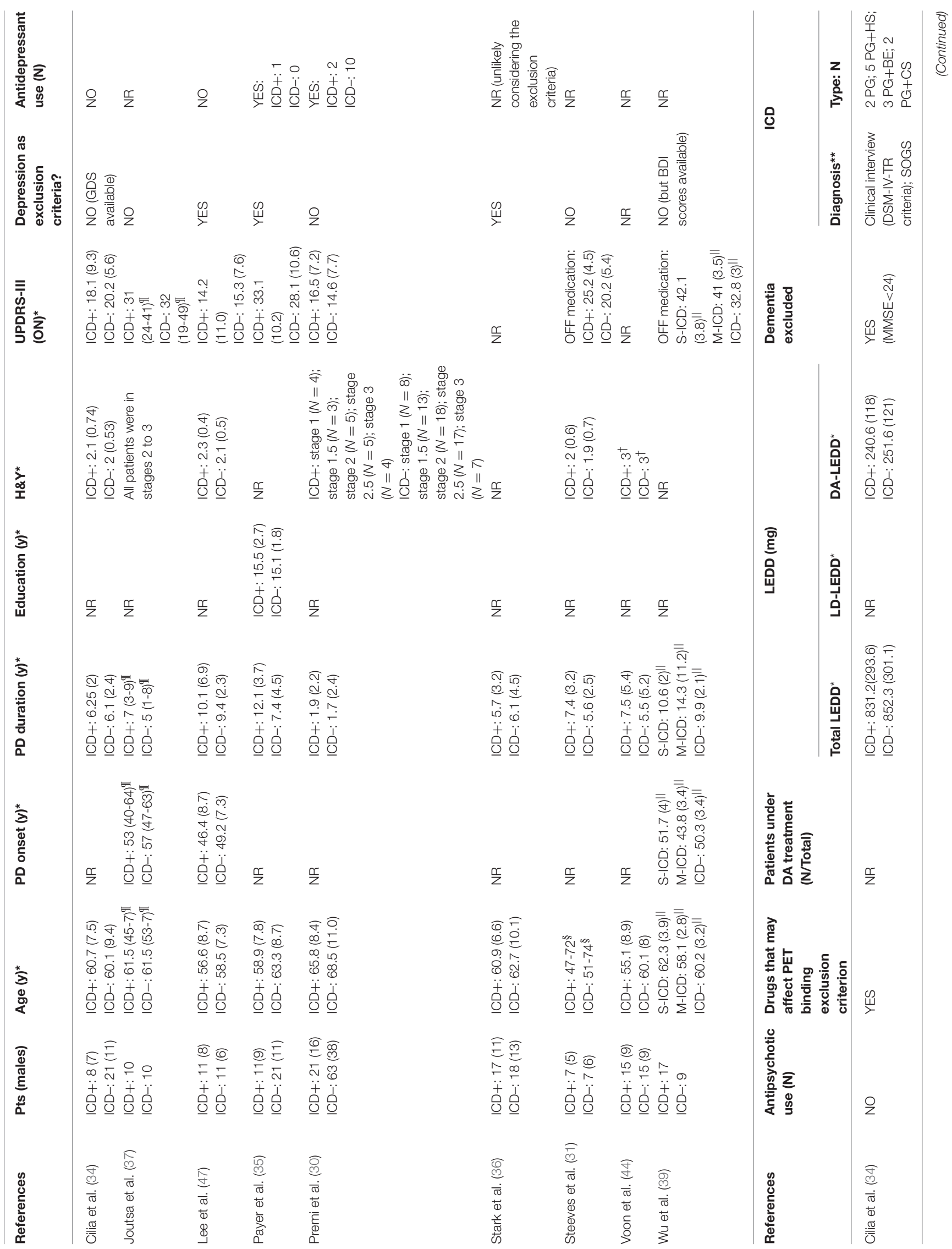




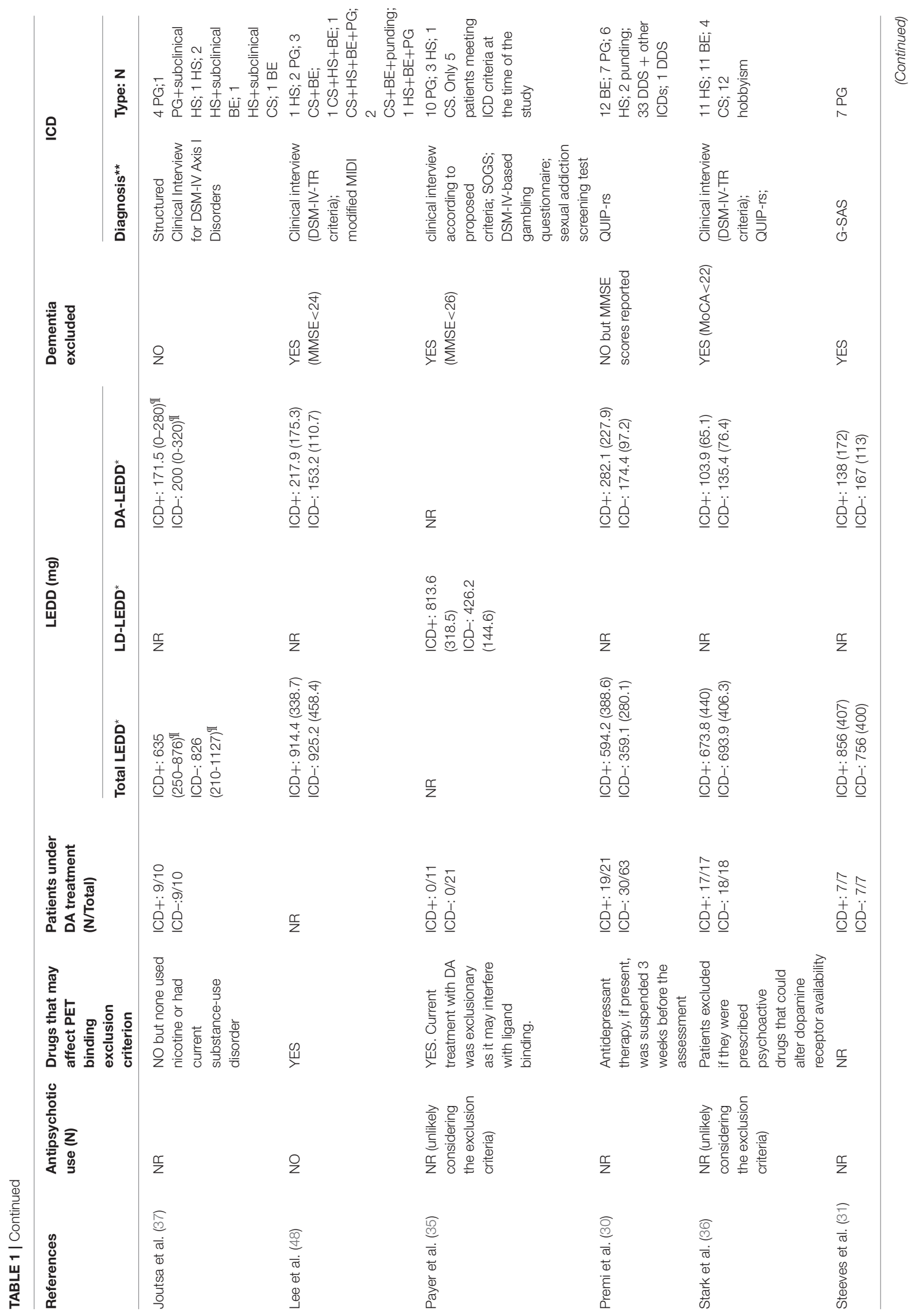




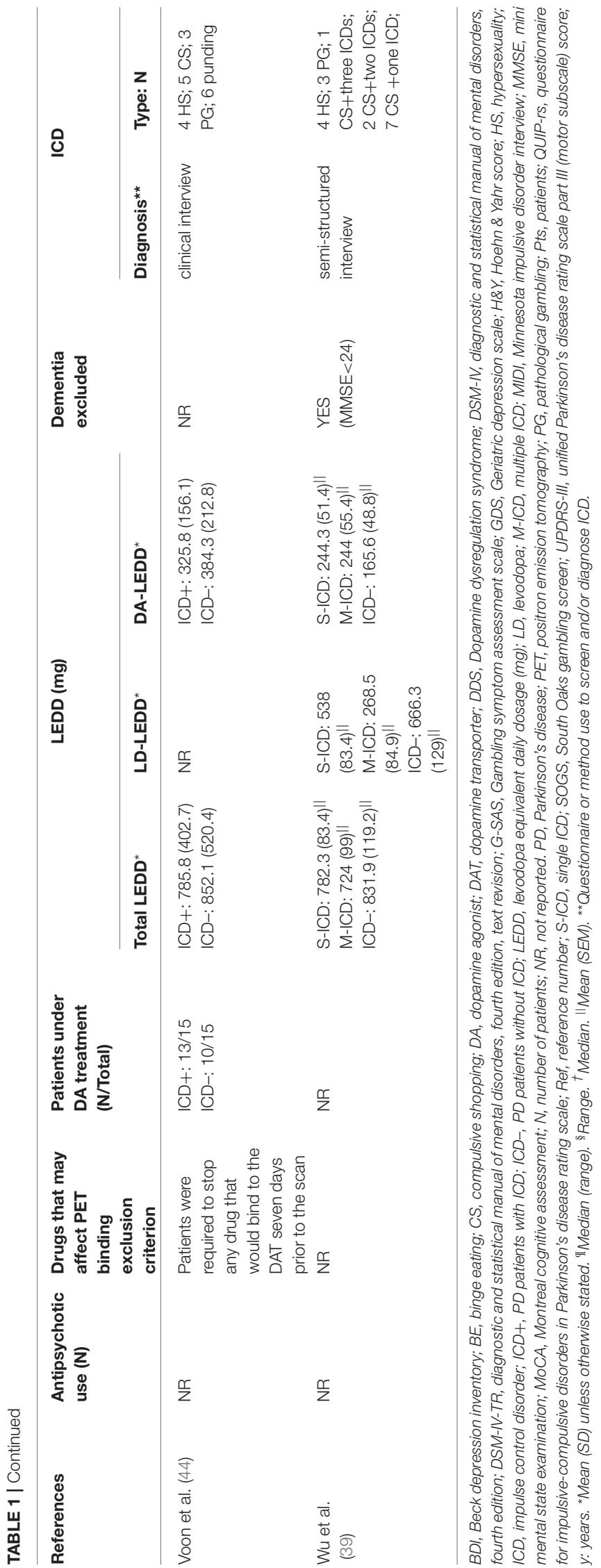

these studies were merged by calculating the pooled means and SDs.

Seven studies provided means and SDs for putamen and caudate separately $(30,35-37,39,44,48)$. For these studies, putamen and caudate measures were merged to generate a measure of the whole dorsal striatum, according to Howes et al. (43). To this aim, the means of the dopaminergic index in the putamen and caudate were weighed by their volumes to reflect the larger contribution of the putamen compared to the caudate, and averaged (43). Since none of the studies reported the putamen and caudate anatomical volumes, we used those used by Howes et al. (43) and derived from healthy adults $(n=34$, mean age $=32.5$ years, $S D=8.8$ years; mean, $S D$ $\mathrm{mm}^{3}$ volume: putamen $=8805,994$; caudate $\left.=5562,865\right) . \mathrm{SD}$ was calculated accounting for the dependency of measures, by assuming a between-measures correlation of $r=0.5$ in the striatal sub-regions. To test whether the whole dorsal striatum measure might have concealed differences in its sub-regions, analyses were repeated considering the putamen and caudate separately.

According to the radiotracer and the imaging approach used, studies were categorized as investigating (i) dopamine transporter level $(30,34,37,44,48)$, (ii) dopamine release (31, 39 ), and (iii) dopamine receptors availability $(31,35,36,39)$. Information about radiotracers used in the studies included in the meta-analysis is reported in Table 3.

In the dopamine transporter level subgroup, three studies (30, 34, 44) used [123I]FP-CIT, a SPECT radiotracer with high affinity for DAT and modest affinity for the serotonin transporter (47); one study (48) used the [18F]FP-CIT radiotracer, which has also cross-affinity to serotonin transporter but a better contrast than [123I]FP-CIT (56); and one study (37) used [18F]fluorodopa, which is a marker of both dopaminergic re-uptake and dopamine synthesis (57).

The pre-synaptic dopamine release subgroup included two studies $(31,39)$ using $[11 \mathrm{C}]$ raclopride, which is a competitive $\mathrm{D}_{2 / 3}$ antagonist sensitive to changes in endogenous dopamine levels $(53)$. Both studies $(31,39)$ used a two PET sessions design, with one baseline scan [i.e., control task (31), neutral cues visual exposure (39)] and one scan during the experimental condition [i.e., gambling task (31), reward cues visual exposure (39)]. The binding potential in baseline condition is a measure of basal level of receptor availability. Conversely, the change in binding potential between baseline and experimental conditions is an indirect measure of alteration in striatal dopamine concentration due to pre-synaptic dopaminergic release. A decrease in binding potential in comparison to baseline is associated with increase in dopamine, while an increase in binding potential in comparison to baseline is associated with a dopamine decrease (53). Therefore, for the pre-synaptic dopamine release studies (31, 39 ), the outcome was the percentage [11C]raclopride binding potential reduction when comparing the experimental and baseline conditions.

Finally, the post-synaptic dopamine receptors availability subgroup included one study (35) with [11C]-(+)-PHNO, a $\mathrm{D}_{3}$-preferring $\mathrm{D}_{2 / 3}$ receptor ligand, and one study (36) with $[18 \mathrm{~F}]$ fallypride, which is one of the high affinity $\mathrm{D}_{2 / 3}$ receptor ligands that allow quantification of both striatal and extrastriatal 
TABLE 2 | Methodological characteristics of the studies included in the meta-analysis.

\begin{tabular}{|c|c|c|c|c|c|c|c|c|}
\hline References & $\begin{array}{l}\text { Imaging } \\
\text { technique }\end{array}$ & Type of tracer & $\begin{array}{l}\text { Reference } \\
\text { region }\end{array}$ & $\begin{array}{l}\text { Imaging } \\
\text { approach }\end{array}$ & $\begin{array}{l}\text { Radiotracer } \\
\text { delivery } \\
\text { method }\end{array}$ & $\begin{array}{l}\text { Drug delivered } \\
\text { prior scan }\end{array}$ & ON/OFF & Withdrawal period \\
\hline Cilia et al. (34) & SPECT & [123I]FP-CIT & Occipital cortex & Single scan & $\begin{array}{l}\text { Intravenous } \\
\text { injection }\end{array}$ & $\begin{array}{l}\text { Thyroid blockade } \\
\text { (oral Lugol solution } \\
10-15 \mathrm{mg} \text { ) } \\
30-40 \text { min before } \\
\text { the injection }\end{array}$ & OFF & $\begin{array}{l}\text { Overnight withdrawal of } \\
\text { dopaminergic } \\
\text { medications }\end{array}$ \\
\hline Joutsa et al. (37) & PET & [18F]fluorodopa & Occipital cortex & Single scan & $\begin{array}{l}\text { Bolus } \\
\text { injection }\end{array}$ & $\begin{array}{l}\text { Carbidopa } 150 \mathrm{mg} \\
1 \mathrm{~h} \text { before the scan }\end{array}$ & OFF & $\begin{array}{l}\text { At least } 12 \mathrm{~h} \text { drug } \\
\text { discontinuation (>24 h } \\
\text { for slow-release } \\
\text { medications) }\end{array}$ \\
\hline Lee et al. (48) & PET & [18F]FP-CIT & Cerebellum & Single scan & $\begin{array}{l}\text { Bolus } \\
\text { injection }\end{array}$ & NO & OFF & $\begin{array}{l}\text { At least } 12 \mathrm{~h} \text { withdrawal } \\
\text { of all PD medications }\end{array}$ \\
\hline Payer et al. (35) & PET & {$[11 \mathrm{C}]-(+)-\mathrm{PHNO}$} & Cerebellum & Single scan & $\begin{array}{l}\text { Bolus } \\
\text { injection }\end{array}$ & NO & OFF & $\begin{array}{l}\text { At least } 8 \mathrm{~h} \text { withdrawal of } \\
\text { levodopa (current DA use } \\
\text { was an exclusion criteria) }\end{array}$ \\
\hline Premi et al. (30) & SPECT & [123I]FP-CIT & Occipital lobe & Single scan & $\begin{array}{l}\text { Intravenous } \\
\text { injection }\end{array}$ & $\begin{array}{l}\mathrm{KClO}_{4} 800 \mathrm{mg} \\
30 \text { min before the } \\
\text { injection }\end{array}$ & NR & NR \\
\hline Stark et al. (36) & PET & [18F]fallypride & Cerebellum & $\begin{array}{l}\text { Three emissions } \\
\text { scans }\end{array}$ & $\begin{array}{l}\text { Bolus } \\
\text { injection }\end{array}$ & $\mathrm{NO}$ & OFF & $\begin{array}{l}\text { Washout was at least } \\
40 \mathrm{~h} \text { for DA and } 16 \mathrm{~h} \text { for } \\
\text { levodopa }\end{array}$ \\
\hline Steeves et al. (31) & PET & [11C]raclopride & Cerebellum & $\begin{array}{l}\text { Two scans in two } \\
\text { separate days within } \\
2 \text { weeks, in } \\
\text { randomized order: } \\
\text { baseline; gambling } \\
\text { task }\end{array}$ & $\begin{array}{l}\text { Ten } \mathrm{mCi} \\
\text { injections }\end{array}$ & NO & OFF & $\begin{array}{l}\text { 12-18 h overnight } \\
\text { withdrawal of PD } \\
\text { medications }\end{array}$ \\
\hline Voon et al. (44) & SPECT & [123I]FP-CIT & Occipital lobe & Single scan & $\begin{array}{l}\text { Slow } \\
\text { intravenous } \\
\text { injection }\end{array}$ & $\begin{array}{l}\text { Thyroid blockade } \\
\text { (oral potassium } \\
\text { iodate) } 24 \mathrm{~h} \text { prior to } \\
\text { the study }\end{array}$ & ON & NO \\
\hline Wu et al. (39) & PET & [11C]raclopride & Cerebellum & $\begin{array}{l}\text { Two scans in } 2 \\
\text { separate weekdays } \\
\text { mornings: neutral } \\
\text { stimuli; } \\
\text { reward-related } \\
\text { stimuli }\end{array}$ & $\begin{array}{l}\text { Bolus } \\
\text { injection }\end{array}$ & $\mathrm{NO}$ & OFF & $\begin{array}{l}12 \mathrm{~h} \text { withdrawal of PD } \\
\text { medications }\end{array}$ \\
\hline
\end{tabular}

$D A$, dopamine agonist; $m C i$, millicurie; PD, Parkinson's disease; PET, positron emission tomography; SPECT, single-photon emission computed tomography.

binding. Two studies $(31,39)$ with [11C]raclopride were also included in the post-synaptic dopamine receptors availability analysis; for these studies the outcome was the value reported for the baseline conditions.

A total of 292 subjects were included in the meta-analysis, 117 were PD patients with ICD (age range: $45-72$ years; PD duration: 1.9-14.3 years; H\&Y: 2-3; UPDRS-III score ON medication: 14.2-41) and 175 were PD patients without ICD (age: 51-74 years; PD duration: 1-9.9 years; H\&Y stage: 1.9-3; UPDRS-III score ON medication: 14.6-49) (Table 1).

Four meta-analyses were performed for the dopamine transporter levels in the ventral striatum, dorsal striatum, putamen, and caudate. Two meta-analyses were performed for the pre-synaptic dopamine release in the ventral and dorsal striatum; the putamen and caudate were not explored for this outcome, because only one study provided separate values for these two structures (39). Four meta-analyses were performed for the post-synaptic dopamine receptors availability in the ventral striatum, dorsal striatum, putamen, and caudate. Results of the meta-analyses are provided in Table 4.

\section{Dopamine Transporter Levels}

Compared to the ICD- group, tracer binding in the ICD+ group was significantly reduced in the dorsal striatum $(\mathrm{SDM}=-0.45$; 95\% CI: $-0.77,-0.13 ; Z=2.76 ; p=0.006)$ but not in the ventral striatum $(\mathrm{SDM}=-0.91 ; 95 \% \mathrm{CI}:-2.10,0.27 ; Z=$ $1.51 ; p=0.13)$. When dorsal striatum sub-regions were analyzed separately, both putamen (SDM $=-0.46$; 95\% CI: $-0.80,-0.11$; $Z=2.61 ; p=0.009)$ and caudate (SDM $=-0.38 ; 95 \% \mathrm{CI}:-0.73$, $-0.04 ; Z=2.18 ; p=0.03)$ tracer bindings were significantly reduced in the ICD+ vs. ICD- (Figure 2, Table 4).

Heterogeneity was low for the dorsal striatum $\left(\chi^{2}=1.99\right.$, $\left.p=0.74, I^{2}=0 \%\right)$, putamen $\left(\chi^{2}=1.43, p=0.70, I^{2}=\right.$ $0 \%)$, and caudate $\left(\chi^{2}=1.79, p=0.62, I^{2}=0 \%\right)$. However, 
TABLE 3 | Radiotracers used in studies included in the meta-analysis.

\begin{tabular}{|c|c|c|}
\hline $\begin{array}{l}\text { Type of } \\
\text { tracer }\end{array}$ & Study & $\begin{array}{l}\text { Function and } \\
\text { characteristics }\end{array}$ \\
\hline [123I]FP-CIT & $\begin{array}{l}\text { Cilia et al. } \\
\text { (34); Premi } \\
\text { et al. (30); } \\
\text { Voon et al. } \\
\text { (44) }\end{array}$ & $\begin{array}{l}\text { SPECT radiotracer with high } \\
\text { affinity for DAT (49) and } \\
\text { serotonin transporter }(50)\end{array}$ \\
\hline [18F]FP-CIT & Lee et al. (48) & $\begin{array}{l}\text { SPECT radiotracer with high } \\
\text { affinity for DAT with high } \\
\text { signal-to-noise ratio and } \\
\text { kinetics (51) }\end{array}$ \\
\hline [18F]fluorodopa & $\begin{array}{l}\text { Joutsa et al. } \\
(37)\end{array}$ & $\begin{array}{l}\text { PET radiotracer for both } \\
\text { presynaptic dopamine } \\
\text { metabolism (synthesis) (52) } \\
\text { and striatal dopamine } \\
\text { uptake }\end{array}$ \\
\hline [11C]raclopride & $\begin{array}{l}\text { Steeves et al. } \\
\text { (31); Wu et al. } \\
\text { (39) }\end{array}$ & $\begin{array}{l}\text { PET selective D2/D3 } \\
\text { antagonist sensitive to } \\
\text { changes in endogenous } \\
\text { dopamine levels; it can be } \\
\text { used to assess both basal } \\
\text { levels of receptor availability } \\
\text { and changes in availability } \\
\text { caused by alterations in } \\
\text { striatal dopamine } \\
\text { concentration (53) }\end{array}$ \\
\hline $\begin{array}{l}{[11 \mathrm{C}]-(+)-} \\
\mathrm{PHNO}\end{array}$ & $\begin{array}{l}\text { Payer et al. } \\
\text { (35) }\end{array}$ & $\begin{array}{l}\text { PET ligand with high affinity } \\
\text { and selectivity for } D_{3} \\
\text { receptors (54) }\end{array}$ \\
\hline [18F]fallypride & $\begin{array}{l}\text { Stark et al. } \\
(36)\end{array}$ & $\begin{array}{l}\text { PET ligand with high affinity } \\
\text { to } D_{2 / 3} \text { receptors in striatal } \\
\text { and extrastriatal regions (55) }\end{array}$ \\
\hline
\end{tabular}

DAT, dopamine transporter; PET, positron emission tomography; SPECT, single-photon emission computed tomography.

heterogeneity in the ventral striatum was high $\left(\chi^{2}=10.14, p=\right.$ $0.006, I^{2}=80 \%$; Figure 2 ). Sensitivity analysis was performed by excluding Premi et al. (30), which enrolled 12 patients under anti-depressant treatment that was suspended 3 weeks before assessment. Exclusion of Premi et al. (30) did not change overall effect size for dorsal striatum (SDM $=-0.58$; 95\% CI: -0.99 , $-0.16 ; Z=2.73 ; p=0.006$ ), putamen (SDM $=-0.54 ; 95 \% \mathrm{CI}$ : $-1.02,-0.06 ; Z=2.23 ; p=0.03)$, and caudate (SDM $=-0.54$; 95\% CI: $-1.02,-0.07 ; Z=2.24 ; p=0.03)$, and heterogeneity (dorsal striatum: $\chi^{2}=1.07, p=0.78, I^{2}=0 \%$; putamen: $\chi^{2}=$ 1.19, $p=0.55, I^{2}=0 \%$; caudate: $\chi^{2}=0.87, p=0.65, I^{2}=0 \%$ ).

\section{Pre-synaptic Dopamine Release}

ICD + group, compared to the ICD- group, showed reduced binding in the ventral striatum in response to reward-related stimuli/gambling task $(\mathrm{SDM}=-1.04 ; 95 \% \mathrm{CI}:-1.73,-0.35 ; Z=$ $2.95 ; p=0.003)$, but not in the dorsal striatum ( $\mathrm{SDM}=-0.36$; 95\% CI: $-1.01,0.28 ; Z=1.10 ; p=0.27$; Figure 3, Table 4).

Heterogeneity was low for both ventral $\left(\chi^{2}=0.22, p=0.64\right.$, $\left.I^{2}=0 \%\right)$ and dorsal $\left(\chi^{2}=0.42, p=0.52, I^{2}=0 \%\right)$ striatal regions (Figure 3).

\section{Post-synaptic Dopamine Receptors Availability}

Post-synaptic dopamine receptor bindings potentials did not differ between ICD+ and ICD- groups in the ventral striatum $(\mathrm{SDM}=-1.29 ; 95 \% \mathrm{CI}:-2.68,0.10 ; Z=1.82 ; p=0.07)$, dorsal striatum $(\mathrm{SDM}=-0.69 ; 95 \% \mathrm{CI}:-1.86,0.48 ; Z=1.16 ; p=$ $0.25)$, putamen $(\mathrm{SDM}=-1.06 ; 95 \% \mathrm{CI}:-2.94,0.81 ; Z=1.11$; $p=0.26)$, and caudate (SDM $=-0.59 ; 95 \% \mathrm{CI}:-1.40,0.23 ; Z=$ $1.41 ; p=0.16$; Figure 4, Table 4).

Heterogeneity was high in the ventral striatum $\left(\chi^{2}=26.71, p\right.$ $\left.<0.00001, I^{2}=89 \%\right)$, dorsal striatum $\left(\chi^{2}=21.90, p<0.0001\right.$, $\left.I^{2}=86 \%\right)$, putamen $\left(\chi^{2}=28.99, p<0.00001, I^{2}=93 \%\right)$, and caudate $\left(\chi^{2}=6.86, p=0.03, I^{2}=71 \%\right.$; Figure 4$)$.

Sensitivity analysis was performed by excluding Payer et al. (35), which enrolled one patient taking antidepressant. Exclusion of Payer et al. (13) did not change the overall effect size for the ventral striatum $(\mathrm{SDM}=-1.42 ; 95 \% \mathrm{CI}:-3.54,0.69 ; Z=1.32$; $p=0.19)$, dorsal striatum (SDM $=-0.84$; 95\% CI: $-2.55,0.86$; $Z=0.97 ; p=0.33)$, putamen (SDM $=-1.54 ; 95 \% \mathrm{CI}:-4.87$, $1.80 ; Z=0.90 ; p=0.37)$, and caudate $(\mathrm{SDM}=-0.56 ; 95 \%$ CI: $-1.99,0.87 ; Z=0.77 ; p=0.44$ ), and heterogeneity (ventral striatum: $\chi^{2}=26.58, p<0.00001, I^{2}=92 \%$; dorsal striatum: $\chi^{2}$ $=20.53, p<0.0001, I^{2}=90 \%$; putamen: $\chi^{2}=25.42, p<0.00001$, $I^{2}=96 \%$; caudate: $\left.\chi^{2}=6.86, p=0.009, I^{2}=85 \%\right)$.

\section{DISCUSSION}

This is the first systematic review and meta-analysis on PET/SPECT dopaminergic striatal correlates of ICD in PD. Our aim was to investigate if striatal dopaminergic function differs in PD patients with and without ICD. To this aim, we reviewed and analyzed studies on dopamine transporter levels, presynaptic dopamine release, and post-synaptic $\mathrm{D}_{2 / 3}$ receptors availability in the ventral and dorsal striatum. We found ICD + to be associated with (i) lower DAT levels in the dorsal striatum and in its subdivisions (i.e., putamen, caudate) and (ii) reduced binding (i.e., increased dopamine release) in the ventral striatum in response to reward-related stimuli or gambling task, but (iii) no relationship between ICD+ and striatal post-synaptic receptors availability in either the dorsal or ventral striatum.

\section{Dopamine Transporter Levels}

ICD+ group showed lower dorsal striatum DAT binding than the ICD- one.

In the striatum, DAT is localized in axon varicosities and terminals that contain synaptic vesicles, as well as in nonsynaptic region where it regulates and terminates extracellular dopamine activity (44). Therefore, reduced DAT might reflect more pronounced dorsal striatal dopaminergic terminal loss, functional DAT downregulation, or genetically determined lower membrane expression on otherwise normal neurons (34).

The hypothesis of more severe degeneration of nigrostriatal projections in ICD+ patients is supported by a recent metaanalysis of case-control studies showing that the risk of ICD in PD increases with disease duration and being medicated for PD (58), two factors that are directly correlated with the amount of 
TABLE 4 | Results of the meta-analysis.

\begin{tabular}{|c|c|c|c|c|c|c|c|c|c|}
\hline \multirow[t]{2}{*}{ Outcome } & \multirow[t]{2}{*}{$\mathbf{K}$} & \multirow[t]{2}{*}{$N$} & \multicolumn{4}{|c|}{ Random-effect model results } & \multicolumn{3}{|c|}{ Heterogeneity } \\
\hline & & & SMD & {$[95 \% \mathrm{Cl}]$} & $\mathbf{Z}$ & $p$ & $x^{2}$ & $p$ & $I^{2}(\%)$ \\
\hline $\begin{array}{l}\text { Dopamine transporter } \\
\text { level-ventral striatum }\end{array}$ & 3 & 71 & -0.91 & {$[-2.10,0.27]$} & 1.51 & 0.13 & 10.14 & 0.006 & 80 \\
\hline $\begin{array}{l}\text { Dopamine transporter } \\
\text { level-dorsal striatum }\end{array}$ & 5 & 184 & -0.45 & {$[-0.77,-0.13]$} & 2.76 & 0.006 & 1.99 & 0.74 & 0 \\
\hline $\begin{array}{l}\text { Dopamine transporter } \\
\text { level-putamen }\end{array}$ & 4 & 155 & -0.46 & {$[-0.80,-0.11]$} & 2.61 & 0.009 & 1.43 & 0.70 & 0 \\
\hline $\begin{array}{l}\text { Dopamine transporter } \\
\text { level-caudate }\end{array}$ & 4 & 155 & -0.38 & {$[-0.73,-0.04]$} & 2.18 & 0.03 & 1.79 & 0.62 & 0 \\
\hline $\begin{array}{l}\text { Dopamine release-ventral } \\
\text { striatum }\end{array}$ & 2 & 40 & -1.04 & {$[-1.73,-0.35]$} & 2.95 & 0.003 & 0.22 & 0.64 & 0 \\
\hline $\begin{array}{l}\text { Dopamine release-dorsal } \\
\text { striatum }\end{array}$ & 2 & 40 & -0.36 & {$[-1.01,0.28]$} & 1.10 & 0.27 & 0.42 & 0.52 & 0 \\
\hline $\begin{array}{l}\text { Receptors } \\
\text { availability-ventral striatum }\end{array}$ & 4 & 107 & -1.29 & {$[-2.68,0.10]$} & 1.82 & 0.07 & 26.71 & $<0.00001$ & 89 \\
\hline $\begin{array}{l}\text { Receptors availability-dorsal } \\
\text { striatum }\end{array}$ & 4 & 107 & -0.69 & {$[-1.86,0.48]$} & 1.16 & 0.25 & 21.90 & $<0.00001$ & 86 \\
\hline $\begin{array}{l}\text { Receptors } \\
\text { availability-putamen }\end{array}$ & 3 & 93 & -1.06 & {$[-2.94,0.81]$} & 1.11 & 0.26 & 28.99 & $<0.00001$ & 93 \\
\hline $\begin{array}{l}\text { Receptors } \\
\text { availability-caudate }\end{array}$ & 3 & 93 & -0.59 & {$[-1.40,0.23]$} & 1.41 & 0.16 & 6.86 & 0.03 & 71 \\
\hline
\end{tabular}

$K$, number of studies; N, number of participants; SMD, standardized mean difference; $\mathrm{Cl}$, confidence interval. $P$ values below the significance level ( $p<0.05)$ are reported in italics.

nigrostriatal loss. Moderator analysis for these two factors was not possible, because of the small number of studies included in the meta-analysis.

The lower DAT binding in ICD + may also reflect medicationrelated DAT downregulation, but DAT regulation by DRT was found to be modest $(44,59)$. It is unlikely that lower DAT binding is a compensatory effect of medication, as longitudinal studies on drug naïve PD patients show that dorsal striatal DAT downregulation precedes DRT initiation $(15,60)$. SPECT findings are further supported by a genetic study showing an association between ICD in PD and a variant of the dopamine transporter gene, i.e., 9-repeat allele of the SLC6A3 (61); this variant results in lower presynaptic DAT expression, reduced synaptic clearance, and increased DA availability in the synaptic space (62).

\section{Pre-synaptic Dopamine Release}

$\mathrm{ICD}+$ group showed reduced binding potential in ventral but not dorsal striatum when exposed to reward-related cues or when engaged in a gambling task.

Participants to a gambling task are required to actively choose options associated either with reward or penalty and process related feedback. Conversely, in reward-related cues paradigms, participants passively view neutral or reward-related stimuli (e.g., food, erotic pictures, gambling, or shopping related activities) without any active choice. Albeit being different, these tasks share neurobiological underpinnings. In pathological gamblers, reductions of ventral striatal and ventromedial prefrontal cortex activity have been documented in a gambling task (63) and reward-related reactivity has been shown to involve the dorsal lateral prefrontal cortex network (64) that is functionally connected to the ventral striatum.

[11C]raclopride is sensitive to competition from endogenously released dopamine to a stimulus, therefore decreased binding potential found in ICD + vs. ICD- groups in response to gambling tasks or rewarding stimuli reflects increased dopamine release. These findings are in keeping with functional imaging studies of behavioral and pharmacological addiction in the general population, whereby monetary and sexual stimuli elicit the same patterns of striatal activation as recreational drugs $(31,65)$. Increased dopamine release during a gambling task has been reported in pathological gamblers $(66,67)$ and it correlates both with gambling severity (68) and increased excitement levels despite lower performances (66). This may be the consequence of conditioned response to the reward-related or gambling cues, although increased dopaminergic release has been observed also for unconditioned stimuli (39). Whether the increased dopamine release in the ventral striatum exists in the premorbid phase therefore representing a vulnerability factor or it is the consequence of repeated exposure to gambling or rewarding-related stimulus $(69,70)$, to DRT $(71)$, or a combination of these factors (31) is unknown. Only preclinical models and prospective studies can address this point.

These findings have important implications, since the exposure to any reward-related cue (e.g., through advertisement) may have the potential to increase abnormal dopamine release in vulnerable PD patients (72), as supported by a study showing increased dopamine release in single ICD PD patients to rewardcues not related to their ICD (e.g., gamblers to food-related cues) (39). 
A

Dopamine transporter levels ventral striatum

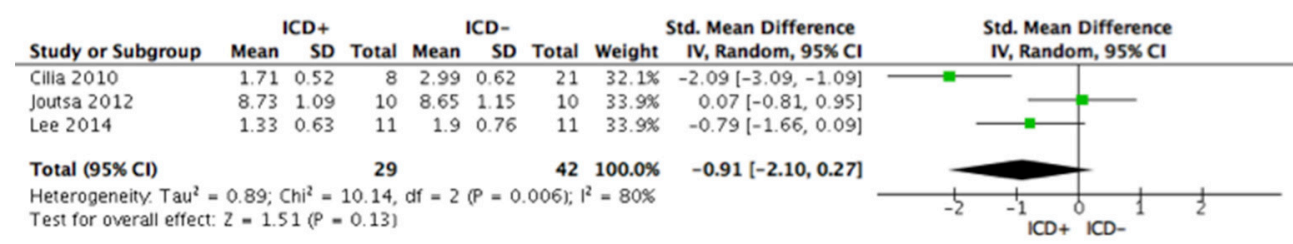

B

Dopamine transporter levels dorsal striatum

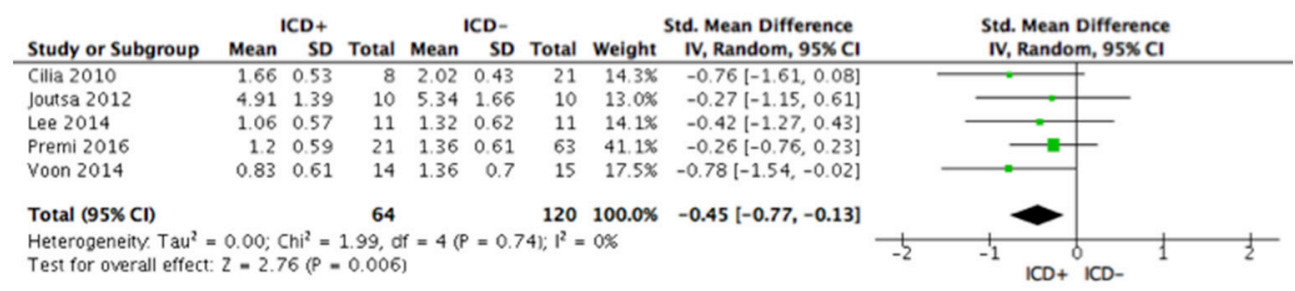

C

\section{Dopamine transporter levels putamen}

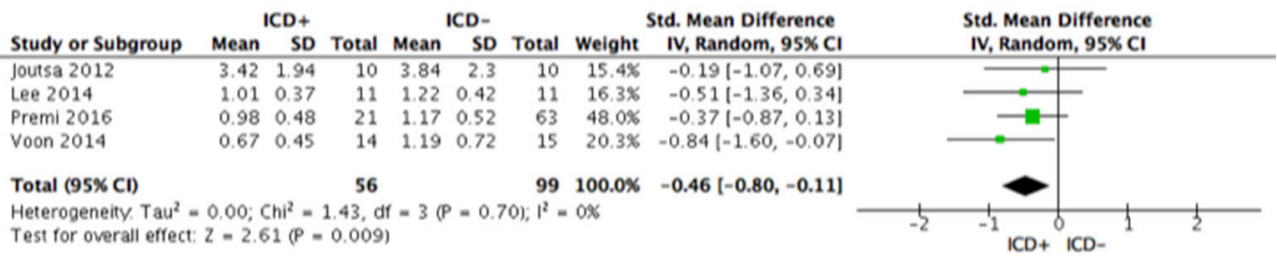

D

Dopamine transporter levels caudate

\begin{tabular}{|c|c|c|c|c|c|c|c|c|c|c|}
\hline Study or Subgroup & \multicolumn{3}{|c|}{$\mathrm{ICD}+$} & \multicolumn{3}{|c|}{ ICD- } & \multicolumn{2}{|r|}{ Std. Mean Difference } & \multicolumn{2}{|c|}{$\begin{array}{l}\text { Std. Mean Difference } \\
\text { IV, Random, } 95 \% \mathrm{Cl}\end{array}$} \\
\hline Joutsa 2012 & 7.28 & 1.4 & 10 & 7.71 & 1.9 & 10 & $15.2 \%$ & $-0.25[-1.13,0.63]$ & & \\
\hline Lee 2014 & 1.15 & 0.52 & 11 & 1.49 & 0.75 & 11 & $16.3 x$ & $-0.51[-1.36,0.35]$ & & — \\
\hline Premi 2016 & 1.56 & 0.46 & 21 & 1.66 & 0.48 & 63 & $48.2 \%$ & $-0.21[-0.70,0.29]$ & $\longrightarrow$ & - \\
\hline Voon 2014 & 1.1 & 0.63 & 14 & 1.63 & 0.66 & 15 & $20.4 \%$ & $-0.80[-1.56,-0.04]$ & & \\
\hline Total $(95 \% \mathrm{CI})$ & & & 56 & & & 99 & $100.0 \%$ & $-0.38[-0.73,-0.04]$ & & \\
\hline $\begin{array}{l}\text { Heterogeneity. Tau } \\
\text { Test for overall effect }\end{array}$ & $\begin{array}{l}00 ; 0 \\
-2.1\end{array}$ & $\begin{array}{l}\mathrm{hi}^{2}= \\
8(\mathrm{P}\end{array}$ & $\begin{array}{l}1.79,0 \\
0.031\end{array}$ & if $=3$ & $=0.6$ & $21 ; 1^{2}=$ & $=0 \%$ & & $\mathrm{ICD}+$ & ICD- \\
\hline
\end{tabular}

FIGURE 2 | Forest plots for dopamine transporter levels. Here are reported forest plots for dopamine transporter levels in the ventral striatum (A), dorsal striatum (B), putamen (C), and caudate (D). Standardized mean difference represents Hedges's g effect size. The size of the square indicates the weight of the study. The horizontal line represents the 95\% confidence interval. The diamond represents the pooled effect size. Negative effect sizes indicate lower dopamine transporter levels in PD patients with ICD (ICD+) in comparison to those without ICD (ICD-). ICD, impulse control disorder; PD, Parkinson's disease.

There are two other neuropharmacological mechanisms that should be considered. First, in patients treated with dopamine agonists the activation of presynaptic $\mathrm{D}_{2}$-like presynaptic autoreceptors in the mesolimbic system reduces phasic dopamine release in the nucleus accumbens $(25,73,74)$. Therefore, reward responsiveness is blunted and risk propensity enhanced in order to normalize mesolimbic efflux (73). Second, reward detection capacity depends on phasic dopaminergic cell firing. Phasic dopamine dips encode prediction errors therefore providing outcome-related feedback which signal the need of behavioral adjustments as reward contingencies change (75). In rats, a low dose of monoamine-depleting agent reserpine administered together with pramipexole, exacerbated its effects on disadvantageous decision-making without changing pramipexole-induced decrease in the phasic dopamine release. This suggests that the effect of dopamine agonist on ICD may not be caused by changes in phasic dopamine release in the nucleus accumbens (73). Moreover, dopamine agonists tonically 


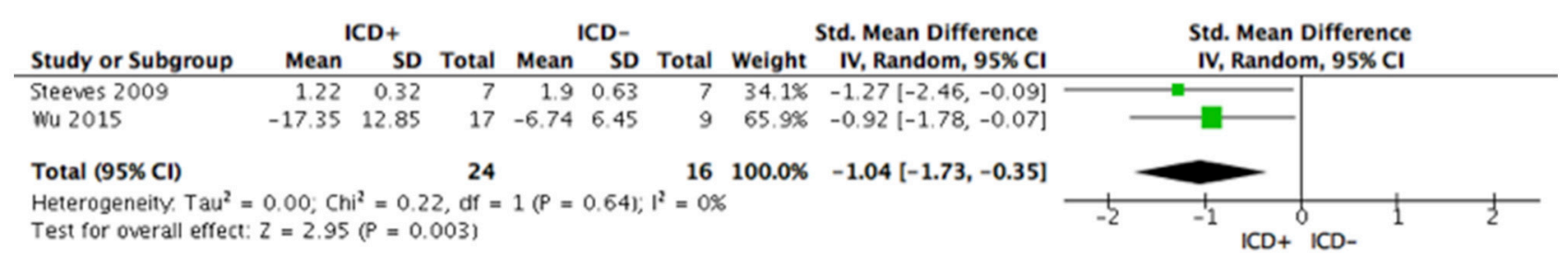

B

\section{Dopamine release dorsal striatum}

\begin{tabular}{lrrrrrrrrrr} 
& \multicolumn{3}{c}{ ICD+ } & \multicolumn{3}{c}{ ICD- } & \multicolumn{3}{c}{ Std. Mean Difference } \\
Study or Subgroup & Mean & SD & Total & Mean & SD & Total & Weight & IV, Random, 95\% CI & Std. Mean Difference \\
IV, Random, 95\% CI
\end{tabular}

FIGURE 3 | Forest plots for dopamine release. Here are reported forest plots for dopamine release in the ventral striatum (A), and in dorsal striatum (B). Standardized mean difference represents Hedges's g effect size. The size of the square indicates the weight of the study. The horizontal line represents the $95 \%$ confidence interval. The diamond represents the pooled effect size. Negative effect sizes indicate lower dopamine release in PD patients with ICD (ICD+) in comparison to those without ICD (ICD-). ICD, impulse control disorder; PD, Parkinson's disease.

bind to $\mathrm{D}_{2}$ receptors irrespective of phasic changes in firing (76).

\section{Post-synaptic Dopamine Receptors Availability}

We did not find changes in $\mathrm{D}_{2 / 3}$ receptors availability between $\mathrm{ICD}+$ and ICD- PD patients. This finding is, to some extent, surprising for a number of considerations. Animal PD models showed increased $\mathrm{D}_{3}$ expression after repeated administration of DRT (35). A PET study found relationships between higher $\mathrm{D}_{3}$ levels, dopamine release in the ventral striatum, and ICD severity in people without PD (77). Preclinical rats models of PD shows that ICD-like behaviors can be triggered by pramipexole $(78,79)$ and ropinirole $(80,81)$, which mainly target $\mathrm{D}_{2 / 3}$ receptors. Polymorphisms of $\mathrm{D}_{2 / 3}$ receptors genes are associated with addictive behaviors in PD (82), and in the general population (83). $\mathrm{D}_{3}$ receptor antagonists may block reward seeking in animal models (84-86).

Different lines of reasoning may explain this apparently paradoxical finding. Heterogeneity was high for this outcome in our meta-analysis, and this may reflect differences in the radiotracers used by the studies we included. However, random effect model does not assume homogeneity of the effect and findings should have been robust to heterogeneity. $D_{2 / 3}$ receptors localize both to pre-synaptic mesolimbic terminal autoreceptors and post-synaptic indirect-pathway medium spiny neurons (36). Therefore, binding of radiotracers may reflect a mix of pre- and post-synaptic changes (35). Moreover, $D_{2 / 3}$ receptors changes have not been universally observed across the spectrum of maladaptive reward-seeking behavior, where reductions are notably absent in primary gambling addiction $(36,87)$. In individuals with substance dependence there is lower $\mathrm{D}_{2 / 3}$ receptors availability than healthy controls (88), but no differences have been reported in pathological gamblers (66, 67).

\section{Limitations and Future Directions}

The main limitation of the present meta-analysis is the small number of studies included, and consequently the low statistical power, which impede any definite conclusions on the mechanisms underlying ICD in PD. The small number of studies hampered a moderator analysis, which would have added information on the variables potentially contributing to our results. Our data suggest that more studies with large numbers of patients are needed. They should have a longitudinal design with drug naïve patients, to clarify the causative relations between striatal dopaminergic changes and ICD, and whether they are pre-morbid vulnerability traits, or a consequence of DRT. Current cross-sectional studies may only document associative links. Future studies should incorporate a healthy control group $(34,35,48)$, as some dopaminergic changes might be age-related and not directly linked to PD or ICD (89).

PET/SPECT studies on extrastriatal regions, which interact with the striatum in the control of motivated and addictive behavior $(37,48)$, are still scarce, and focus on a range of different structures, impeding a meta-analysis. The role of extrastriatal dopaminergic changes should be assessed. At the time of our literature search, five studies reported data on extrastriatal regions, including the orbitofrontal (37), medial orbitofrontal (35), ventromedial prefrontal (48), and left 
Receptors availability ventral striatum

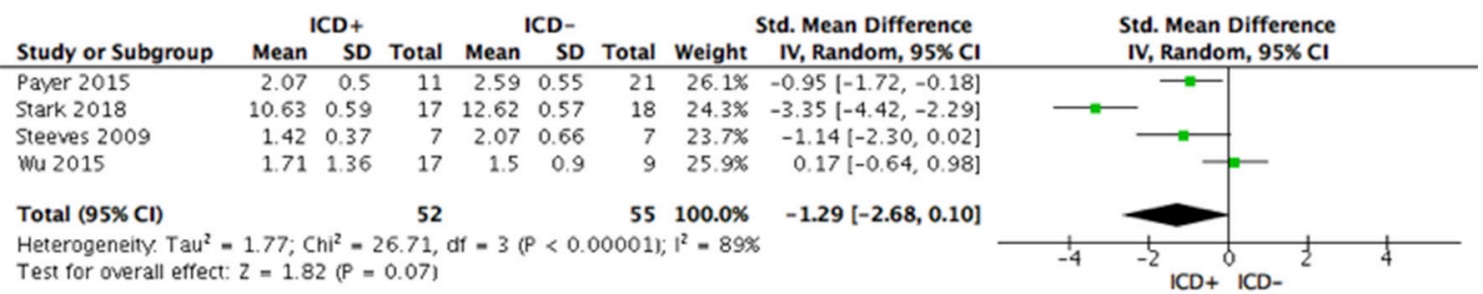

B

Receptors availability dorsal striatum

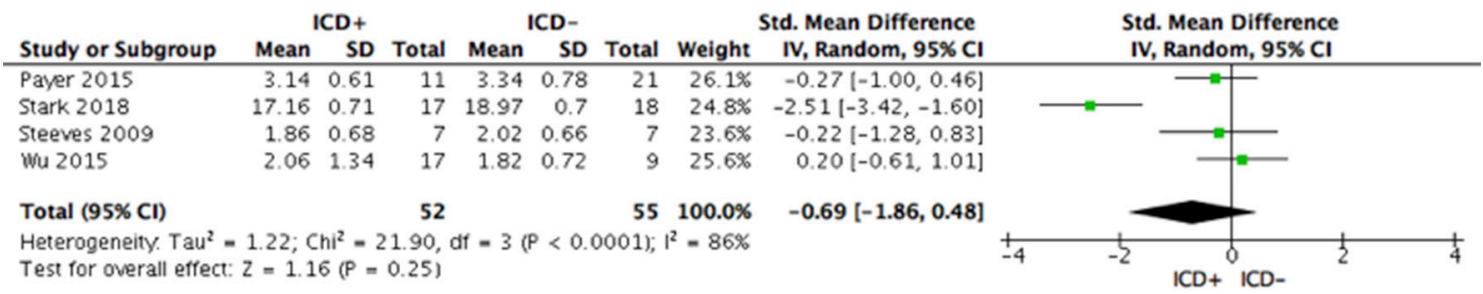

C Receptors availability putamen

\begin{tabular}{|c|c|c|c|c|c|c|c|c|c|c|}
\hline Study or Subgroup & \multicolumn{3}{|c|}{ ICD+ } & \multicolumn{3}{|c|}{ ICD- } & \multicolumn{2}{|r|}{ Std. Mean Difference } & $\begin{array}{l}\text { Std. Mean Difference } \\
\text { IV, Random, } 95 \% \mathrm{CI}\end{array}$ & \\
\hline Payer 2015 & 3.69 & 0.58 & 11 & 3.85 & 0.93 & 21 & $34.0 \%$ & $-0.19[-0.92,0.54]$ & $\rightarrow-$ & \\
\hline Stark 2018 & 18.75 & 0.74 & 17 & 21.18 & 0.72 & 18 & $32.3 \%$ & $-3.25[-4.30,-2.21]$ & $\rightarrow-$ & \\
\hline wu 2015 & 2.23 & 1.77 & 17 & 2 & 0.73 & 9 & $33.7 \%$ & $0.15[-0.66,0.96]$ & & \\
\hline Total $(95 \% \mathrm{CI})$ & & & 45 & & & 48 & $100.0 \%$ & $-1.06[-2.94,0.81]$ & & \\
\hline $\begin{array}{l}\text { Heterogeneity. Tau }{ }^{2} \\
\text { Test for overall effec }\end{array}$ & $\begin{array}{l}.54 ; \\
=1.1\end{array}$ & $\begin{array}{l}h i^{2}= \\
1(P=\end{array}$ & $\begin{array}{l}8.99, \\
0.261\end{array}$ & $d f=2$ & $<0$ & 0011 & $; 1^{2}=93 \%$ & & $-4 \quad-2$ ICD + ICD- & 4 \\
\hline
\end{tabular}

D

Receptors availability caudate

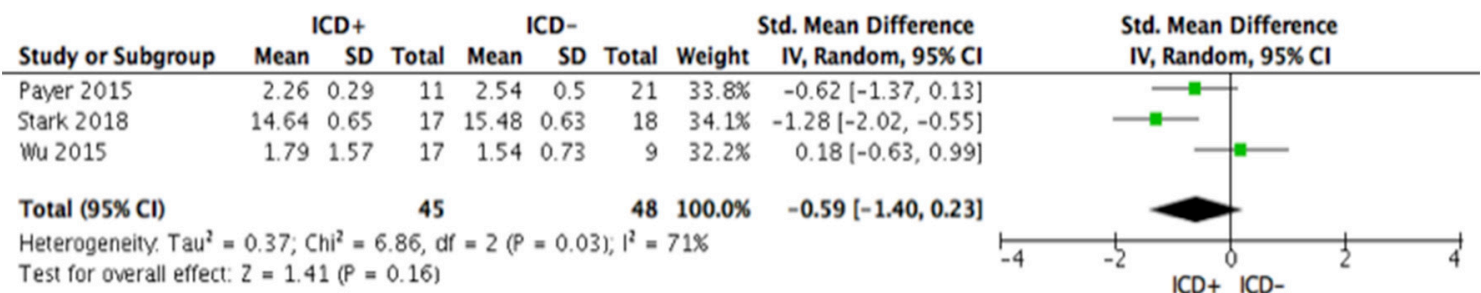

FIGURE 4 | Forest plots for post-synaptic receptors availability. Here are reported forest plots for post-synaptic receptors availability in the ventral striatum (A), dorsal striatum (B), putamen (C), and caudate (D). Standardized mean difference represents Hedges's g effect size. The size of the square indicates the weight of the study. The horizontal line represents the 95\% confidence interval. The diamond represents the pooled effect size. Negative effect sizes indicate lower receptors availability in PD patients with ICD (ICD+) in comparison to those without ICD (ICD-). ICD, impulse control disorder; PD, Parkinson's disease.

anterior cingulate cortex (90), the amygdala (48), substantia nigra (35), globus pallidus (35, 36), ventral pallidus (35), thalamus (36), and the midbrain $(36,90)$. Exploring these areas would be important, since, e.g., abnormal functioning of $\mathrm{D}_{2 / 3}$ midbrain receptors might results in increased dopamine release (91). 
Since the dopamine system may not be the only player in ICD development, multi-modal imaging studies should explore the contribution of serotoninergic systems to ICD in PD $(30,61,92)$.

Finally, ICD in PD was found to be associated with cognitive (worse set-shifting and reward-related decisionmaking), and neuropsychiatric features (increased depression, anxiety, anhedonia, and impulsivity) (93). The potential confounding role of these clinical variables should be considered in future PET/SPECT studies.

\section{CONCLUSIONS}

Our meta-analysis showed specific patterns of dopaminergic dysfunction in the dorsal and ventral striatum in PD patients with ICD. These changes, which, to some extent, differ from those in people with ICD but no $\mathrm{PD}$, may reflect either a preexisting

\section{REFERENCES}

1. Antonini A, Barone P, Bonuccelli U, Annoni K, Asgharnejad M, Stanzione P. ICARUS study: prevalence and clinical features of impulse control disorders in Parkinson's disease. J Neurol Neurosurg Psychiatry (2017) 88:317-24. doi: 10.1136/jnnp-2016-315277

2. Erga AH, Alves G, Larsen JP, Tysnes OBR, Pedersen KF. Impulsive and compulsive behaviors in Parkinson Disease: the Norwegian ParkWest Study. J Parkinsons Dis. (2017) 7:183-91. doi: 10.3233/JPD-160977

3. Rodríguez-Violante M, González-Latapi P, Cervantes-Arriaga A, CamachoOrdoñez A, Weintraub D. Impulse control and related disorders in Mexican Parkinson's disease patients. Park Relat Disord. (2014) 20:907-10. doi: 10.1016/j.parkreldis.2014.05.014

4. Joutsa J, Martikainen K, Vahlberg T, Voon V, Kaasinen V. Impulse control disorders and depression in Finnish patients with Parkinson's disease. Parkinsonism Relat Disord. (2012) 18:155-60. doi: 10.1016/j.parkreldis.2011.09.007

5. Weintraub D, Koester J, Potenza M, Siderowf A, Stacy M, Voon $\mathrm{V}$, et al. Impulse control disorders in Parkinson Disease: a crosssectional study of 3090 patients. Arch Neurol. (2010) 67:589-95. doi: 10.1001/archneurol.2010.65

6. Perez-Lloret S, Rey MV, Fabre N, Ory F, Spampinato U, Brefel-Courbon C, et al. Prevalence and pharmacological factors associated with impulse-control disorder symptoms in patients with parkinson disease. Clin Neuropharmacol. (2012) 35:261-5. doi: 10.1097/WNF.0b013e31826e6e6d

7. Valença GT, Glass PG, Negreiros NN, Duarte MB, Ventura LMGB, Mueller $\mathrm{M}$, et al. Past smoking and current dopamine agonist use show an independent and dose-dependent association with impulse control disorders in Parkinson's disease. Parkinsonism Relat Disord. (2013) 19:698-700. doi: 10.1016/j.parkreldis.2013.03.004

8. Weintraub D, Papay K, Siderowf A, Parkinson's Progression Markers Initiative. Screening for impulse control symptoms in patients with de novo Parkinson disease: a case-control study. Neurology (2013) 80:176-80. doi: 10.1212/WNL.0b013e31827b915c

9. Antonini A, Siri C, Santangelo G, Cilia R, Poletti M, Canesi M, et al. Impulsivity and compulsivity in drug-naïve patients with Parkinson's disease. Mov Disord. (2011) 26:464-8. doi: 10.1002/mds.23501

10. Dodd ML, Klos KJ, Bower JH, Geda YE, Josephs KA, Ahlskog JE. Pathological gambling caused by drugs used to treat Parkinson Disease. Arch Neurol. (2005) 62:1377-81. doi: 10.1001/archneur.62.9.noc50009

11. Munhoz RP, Fabiani G, Becker N, Teive HAG. Increased frequency and range of sexual behavior in a patient with Parkinson's disease after use of pramipexole: a case report. J Sex Med. (2009) 6:1177-80. doi: 10.1111/j.1743-6109.2008.00861.x neural trait vulnerability for impulsivity or the expression of a maladaptive synaptic plasticity under non-physiological dopaminergic stimulation (30).

\section{AUTHOR CONTRIBUTIONS}

The study has been designed by AM, NE, and ST. Data have been gathered by AM and DDL, under the supervision of MS and ST. Data have been analyzed by AM. The manuscript has been drafted by AM, NE, and ST. AM, DDL, FL, MS, NE, and ST revised the manuscript.

\section{ACKNOWLEDGMENTS}

The study has been supported by a Ph.D. scholarship from Keele University. We would like to thank Federico Del Maschio for advice on the statistical analysis.
12. Seedat S, Kesler S, Niehaus DJH, Stein DJ. Pathological gambling behaviour: emergence secondary to treatment of Parkinson's disease with dopaminergic agents. Depress Anxiety (2000) 11:185-6. doi: 10.1002/1520-6394(2000)11:4<185::AID-DA8>3.0.CO;2-H

13. Mamikonyan E, Siderowf AD, Duda JE, Potenza MN, Horn S, Stern MB, et al. Long-term follow-up of impulse control disorders in Parkinson's disease. Mov Disord. (2008) 23:75-80. doi: 10.1002/mds.21770

14. Bastiaens J, Dorfman, BJ, Christos PJ, Nirenberg MJ, Bastiaens J, Dorfman BJ, et al. Prospective cohort study of impulse control disorders in Parkinson's disease. Mov Disord. (2013) 28:327-33. doi: 10.1002/mds.25291

15. Smith KM, Xie SX, Weintraub D. Incident impulse control disorder symptoms and dopamine transporter imaging in Parkinson disease. J Neurol Neurosurg Psychiatry (2016) 87:864-70. doi: 10.1136/jnnp-2015311827

16. Corvol J-C, Artaud F, Cormier-Dequaire F, Rascol O, Durif F, Derkinderen $\mathrm{P}$, et al. Longitudinal analysis of impulse control disorders in Parkinson disease. Neurology (2018) 91:e189-201. doi: 10.1212/WNL.00000000000 05816

17. Wade TR, De Wit H, Richards JB. Effects of dopaminergic drugs on delayed reward as a measure of impulsive behavior in rats. Psychopharmacology (Berl) (2000) 150:90-101. doi: 10.1007/s002130000402

18. Bizot JC, David S, Trovero F. Effects of atomoxetine, desipramine, damphetamine and methylphenidate on impulsivity in juvenile rats, measured in a T-maze procedure. Neurosci Lett. (2011) 489:20-4. doi: 10.1016/j.neulet.2010.11.058

19. Evenden JL, Ryan CN. The pharmacology of impulsive behaviour in rats: the effects of drugs on response choice with delays of reinforcement. Psychopharmacology (1996) 128:161-70. doi: 10.1007/PL00005486

20. Helms CM, Reeves JM, Mitchell SH. Impact of strain and D-amphetamine on impulsivity (delay discounting) in inbred mice. Psychopharmacology (2006) 188:144-51. doi: 10.1007/s00213-006-0478-0

21. Hand DJ, Fox AT, Reilly MP. Differential effects of d-amphetamine on impulsive choice in spontaneously hypertensive and Wistar-Kyoto rats. Behav Pharmacol. (2009) 20:549-53. doi: 10.1097/FBP.0b013e3283305ee1

22. Cardinal RN, Robbins TW, Everitt BJ. The effects of d-amphetamine, chlordiazepoxide, $\alpha$-flupenthixol and behavioural manipulations on choice of signalled and unsignalled delayed reinforcement in rats. Psychopharmacology (2000) 152:362-75. doi: 10.1007/s002130000536

23. De Wit H, Enggasser JL, Richards JB. Acute administration of d-amphetamine decreases impulsivity in healthy volunteers. Neuropsychopharmacology (2002) 27:813-25. doi: 10.1016/S0893-133X(02)00343-3

24. Pine A, Shiner T, Seymour B, Dolan RJ. Dopamine, time, and impulsivity in humans. J Neurosci. (2010) 30:8888-96. doi: 10.1523/JNEUROSCI.6028-09.2010 
25. Riba J, Krämer UM, Heldmann M, Richter S, Münte TF. Dopamine agonist increases risk taking but blunts reward-related brain activity. PLoS ONE (2008) 3:e2479. doi: 10.1371/journal.pone.0002479

26. Braak H, Ghebremedhin E, Rüb U, Bratzke H, Del Tredici K. Stages in the development of Parkinson's disease-related pathology. Cell Tissue Res. (2004) 318:121-34. doi: 10.1007/s00441-004-0956-9

27. Voon V, Mehta AR, Hallett M. Impulse control disorders in Parkinson's disease: recent advances. Curr Opin Neurol. (2011) 24:324-30. doi: 10.1097/WCO.0b013e3283489687

28. Claassen DO, Stark AJ, Spears CA, Petersen KJ, Van Wouwe NC, Kessler RM, et al. Mesocorticolimbic hemodynamic response in Parkinson's disease patients with compulsive behaviors. Mov Disord. (2017) 32:1574-83. doi: $10.1002 / \mathrm{mds} .27047$

29. Badgaiyan RD. Imaging dopamine neurotransmission in live human brain. Prog Brain Res. (2014) 211:165-82. doi: 10.1016/B978-0-444-63425-2.00007-6

30. Premi E, Pilotto A, Garibotto V, Bigni B, Turrone R, Alberici A, et al. Impulse control disorder in PD: a lateralized monoaminergic frontostriatal disconnection syndrome? Park Relat Disord. (2016) 30:62-6. doi: 10.1016/j.parkreldis.2016.05.028

31. Steeves TDL, Miyasaki J, Zurowski M, Lang AE, Pellecchia G, Van Eimeren $\mathrm{T}$, et al. Increased striatal dopamine release in Parkinsonian patients with pathological gambling: A [11C] raclopride PET study. Brain (2009) 132:137685. doi: 10.1093/brain/awp054

32. Ouzzani M, Hammady H, Fedorowicz Z, Elmagarmid A, Chalmers T, Smith $\mathrm{H}$, et al. Rayyan-a web and mobile app for systematic reviews. Syst Rev. (2016) 5:210. doi: 10.1186/s13643-016-0384-4

33. Samuel M, Rodriguez-Oroz M, Antonini A, Brotchie JM, Ray Chaudhuri K, Brown RG, et al. Management of impulse control disorders in Parkinson's disease: controversies and future approaches. Mov Disord. (2015) 30:150-9. doi: 10.1002/mds.26099

34. Cilia R, Ko JH, Cho SS, van Eimeren T, Marotta G, Pellecchia G, et al. Reduced dopamine transporter density in the ventral striatum of patients with Parkinson's disease and pathological gambling. Neurobiol Dis. (2010) 39:98-104. doi: 10.1016/j.nbd.2010.03.013

35. Payer DE, Guttman M, Kish SJ, Tong J, Strafella A, Zack M, et al. $\left[{ }^{11} \mathrm{C}\right]-$ $(+)$-PHNO PET imaging of dopamine $\mathrm{D}(2 / 3)$ receptors in Parkinson's disease with impulse control disorders. Mov Disord. (2015) 30:160-6. doi: $10.1002 / \mathrm{mds} .26135$

36. Stark AJ, Smith CT, Lin YC, Petersen KJ, Trujillo P, van Wouwe NC, et al. Nigrostriatal and mesolimbic D 2/3 receptor expression in Parkinson's disease patients with compulsive reward-driven behaviors. J Neurosci. (2018) 38:3230-9. doi: 10.1523/JNEUROSCI.3082-17.2018

37. Joutsa J, Martikainen K, Niemelä S, Johansson J, Forsback S, Rinne $\mathrm{JO}$, et al. Increased medial orbitofrontal [18F]fluorodopa uptake in Parkinsonian impulse control disorders. Mov Disord. (2012) 27:778-82. doi: $10.1002 / \mathrm{mds} .24941$

38. Hozo SP, Djulbegovic B, Hozo I. Estimating the mean and variance from the median, range, and the size of a sample. BMC Med Res Methodol. (2005) 5:13. doi: $10.1186 / 1471-2288-5-13$

39. Wu K, Politis M, O'Sullivan SS, Lawrence AD, Warsi S, Bose S, et al. Single versus multiple impulse control disorders in Parkinson's disease: an (11)C-raclopride positron emission tomography study of reward cue-evoked striatal dopamine release. J Neurol. (2015) 262:1504-14. doi: 10.1007/s00415-015-7722-7

40. The Cochrane Collaboration. Review Manager (RevMan) [Computer program]. Version 5.3. Copenhagen: The Nordic Cochrane Centre (2014).

41. Cohen J. Statistical power analysis for the behavioral sciences. Stat Power Anal Behav Sci. (1977) 567:24-27. doi: 10.1016/B978-0-12-179060-8. 50001-3

42. Higgins JPT, Thompson SG, Deeks JJ, Altman DG. Measuring inconsistency in meta-analyses. BMJ Br Med J. (2003) 327:557-60. doi: 10.1136/bmj.327.7414.557

43. Howes OD, Kambeitz J, Kim E, Stahl D, Slifstein M, Abi-Dargham A, et al. The nature of dopamine dysfunction in schizophrenia and what this means for treatment: meta-analysis of imaging studies. Arch Gen Psychiatry (2012) 69:776-86. doi: 10.1001/archgenpsychiatry.2012.169

44. Voon V, Rizos A, Chakravartty R, Mulholland N, Robinson S, Howell NA, et al. Impulse control disorders in Parkinson's disease: decreased striatal dopamine transporter levels. J Neurol Neurosurg Psychiatry (2014) 85:148-52. doi: 10.1136/jnnp-2013-305395

45. Sterne JAC, Sutton AJ, Ioannidis JPA, Terrin N, Jones DR, Lau J, et al. Recommendations for examining and interpreting funnel plot asymmetry in meta-analyses of randomised controlled trials. BMJ (2011) 343:d4002. doi: $10.1136 /$ bmj.d4002

46. Borenstein M. Effect sizes for continuous data In: Cooper H, Hedges LV, Valentine JC, editors. The Handbook of Research Synthesis and Meta-Analysis. New York, NY: Russell Sage Foundation (2009). p. 221-35.

47. Joling M, Vriend C, van den Heuvel OA, Raijmakers PGHM, Jones PA, Berendse HW, et al. Analysis of extrastriatal ${ }^{123}$ I-FP-CIT binding contributes to the differential diagnosis of Parkinsonian Diseases. J Nucl Med. (2017) 58:1117-23. doi: 10.2967/jnumed.116.182139

48. Lee JY, Seo SH, Kim YK, Yoo HB, Kim YE, Song IC, et al. Extrastriatal dopaminergic changes in Parkinson's disease patients with impulse control disorders. J Neurol Neurosurg Psychiatry (2014) 85:23-30. doi: 10.1136/jnnp-2013-305549

49. Booij J, Tissingh G, Winogrodzka A, Boer GJ, Stoof JC, Wolters EC, et al. Practical benefit of [123I] FP-CIT SPET in the demonstration of the dopaminergic deficit in Parkinson's disease. Eur J Nucl Med. (1997) 24:68-71.

50. Booij J, Jong J De, Bruin K De, Knol R, Win MML De, van Eck-smit BLF. Quantification of striatal dopamine transporters with 123 I-FP-CIT SPECT is influenced by the selective serotonin reuptake inhibitor crossover study in healthy control subjects. J Nucl Med. (2007) 48:359-66.

51. Wang J, Zuo C, Guan Y, Chen Z. 18F-FP-CIT PET imaging and SPM analysis of dopamine transporters in Parkinson's disease in various Hoehn \& Yahr stages. J Neurol. (2006) 254:185-90. doi: 10.1007/s00415-006-0322-9

52. de Vries EFJ, Luurtsema G, Bru M, Elsinga PH, Vaalburg W. Fully automated synthesis module for the high yield one- pot preparation of 6-[18F]fluoro- L -DOPA. Appl Radiat Isot. (1999) 51:389-94.

53. Yoder KK, Kareken DA, Morris ED. What were they thinking? Cognitive states may influence $[11 \mathrm{C}]$ raclopride binding potential in the striatum. Neurosci Lett. (2008) 430:38-42. doi: 10.1016/j.neulet.2007.10.017

54. Narendran R, Slifstein M, Guillin O, Hwang Y, Hwang D, Scher E, et al. Dopamine (D2/3) receptor agonist positron emission tomography radiotracer [11C]-(+)-PHNO is a D3 receptor preferring agonist in vivo. Synapse (2006) 60:485-95. doi: 10.1002/syn.20325

55. Mukherjee J, Christian BT, Dunigan KA, Shi B, Narayanan TK, Satter M, et al. Brain imaging of $18 \mathrm{~F}$-fallypride in normal volunteers: blood analysis distribution, test-retest studies, and preliminary assessment of sensitivity to aging effects on dopamine D-2/D-3 receptors. Synapse (2002) 46:170-88. doi: 10.1002/syn.10128

56. Lee I, Kim JS, Park JY, Byun BH, Park SY, Choi JH, et al. Head-to-head comparison of 18 F-FP-CIT and 123 I-FP-CIT for dopamine transporter imaging in patients with Parkinson's disease: a preliminary study. Synapse (2018) 72:e22032. doi: 10.1002/syn.22032

57. Kaasinen V, Nurmi E, Brück A, Eskola O, Bergman J, Solin O, et al. Increased frontal [18F]fluorodopa uptake in early Parkinson's disease sex differences in the prefrontal cortex. Brain (2001) 124:1125-30. doi: 10.1093/brain/124.6.1125

58. Molde H, Moussavi Y, Kopperud ST, Erga AH, Hansen AL, Pallesen S. Impulse-control disorders in Parkinson's disease: a meta- analysis and review of case - control studies. Front Neurol. (2018) 9:330. doi: $10.3389 /$ fneur. 2018.00330

59. Guttman M, Stewart D, Hussey D, Wilson A, Houle S, Kish S. Influence of L-dopa and pramipexole on striatal dopamine transporter in early PD. Neurology (2001) 56:1559-64. doi: 10.1212/WNL.56.11.1559

60. Vriend C, Nordbeck AH, Booij J, van der Werf YD, Pattij T, Voorn P, et al. Reduced dopamine transporter binding predates impulse control disorders in Parkinson's disease. Mov Disord. (2014) 29:904-11. doi: 10.1002/mds.25886

61. Cilia R, Benfante R, Asselta R, Marabini L, Cereda E, Siri C, et al. Tryptophan hydroxylase type 2 variants modulate severity and outcome of addictive behaviors in Parkinson's disease. Park Relat Disord. (2016) 29:96-103. doi: 10.1016/j.parkreldis.2016.05.017

62. Forbes EE, Brown SM, Kimak M, Ferrell RE, Manuck SB, Hariri AR. Genetic variation in components of dopamine neurotransmission impacts ventral striatal reactivity associated with impulsivity. Mol Psychiatry (2009) 14:60-70. doi: 10.1038/sj.mp.4002086 
63. Reuter J, Raedler T, Rose M, Hand I, Gläscher J, Büchel C. Pathological gambling is linked to reduced activation of the mesolimbic reward system. Nat Neurosci. (2005) 8:147-8. doi: 10.1038/nn1378

64. Crockford DN, Goodyear B, Edwards J, Quickfall J, El-Guebaly N. Cueinduced brain activity in pathological gamblers. Biol Psychiatry (2005) 58:78795. doi: 10.1016/j.biopsych.2005.04.037

65. Volkow ND, Fowler JS, Wang GJ, Baler R, Telang F. Neuropharmacology Imaging dopamine's role in drug abuse and addiction. Neuropharmacology (2009) 56:3-8. doi: 10.1016/j.neuropharm.2008.05.022

66. Linnet J, Møller A, Peterson E, Gjedde A, Doudet D. Dopamine release in ventral striatum during Iowa Gambling Task performance is associated with increased excitement levels in pathological gambling. Addiction (2011) 106:383-90. doi: 10.1111/j.1360-0443.2010.03126.x

67. Linnet J, Peterson E, Doudet DJ, Gjedde A, Møller A. Dopamine release in ventral striatum of pathological gamblers losing money. Acta Psychiatr Scand. (2010) 122:326-33. doi: 10.1111/j.1600-0447.2010.01591.x

68. Joutsa J, Johansson J, Niemelä S, Ollikainen A, Hirvonen MM, Piepponen P, et al. Mesolimbic dopamine release is linked to symptom severity in pathological gambling. Neuroimage (2012) 60:1992-9. doi: 10.1016/j.neuroimage.2012.02.006

69. de Wit H, Stewart J. Reinstatement of cocaine-reinforced responding in the rat. Psychopharmacology (1981) 75:134-43. doi: 10.1007/BF00432175

70. Singer BF, Scott-Railton J, Vezina P. Unpredictable saccharin reinforcement enhances locomotor responding to amphetamine. Behav Brain Res. (2012) 226:340-4. doi: 10.1016/j.bbr.2011.09.003

71. Laruelle M, Abi-dargham A, Dyck CH Van, Rosenblatt W, Zea-ponce Y, Zoghbi SS, et al. SPECT imagingof Striatal Dopamine release after amphetamine challenge. J Nucl Med. (1995) 36:1182-90.

72. O’Sullivan SS, Wu K, Politis M, Lawrence AD, Evans AH, Bose SK, et al. Cueinduced striatal dopamine release in Parkinson's disease-associated impulsivecompulsive behaviours. Brain (2011) 134:969-78. doi: 10.1093/brain/awr003

73. Pes R, Godar SC, Fox AT, Burgeno LM, Strathman HJ, Jarmolowicz DP, et al. Pramipexole enhances disadvantageous decision-making: lack of relation to changes in phasic dopamine release. Neuropharmacology (2017) 114:77-87. doi: 10.1016/j.neuropharm.2016.11.014

74. Pizzagalli DA, Evins AE, Schetter EC, Frank MJ, Pajtas PE, Santesso DL, et al. Single dose of a dopamine agonist impairs reinforcement learning in humans: behavioral evidence from a laboratory-based measure of reward responsiveness. Psychopharmacology (2008) 196:221-32. doi: 10.1007/s00213-007-0957-y

75. Stopper CM, Floresco SB. Dopaminergic circuitry and risk/reward decision making: implications for schizophrenia. Schizophr Bull. (2015) 41:9-14. doi: $10.1093 /$ schbul/sbu165

76. Frank MJ, O'Reilly RC, Seeberger LC. By carrot or by stick: cognitive reinforcement learning in parkinsonism. Science (2004) 306:1940-3. doi: 10.1126/science.1102941

77. Boileau I, Payer D, Chugani B, Lobo DSS, Houle S, Wilson AA, et al. In vivo evidence for greater amphetamine-induced dopamine release in pathological gambling: a positron emission tomography study with [11C]-(+)-PHNO. Mol Psychiatry (2014) 19:1305-13. doi: 10.1038/mp.2013.163

78. Rokosik SL, Napier TC. Pramipexole-induced increased probabilistic discounting: Comparison between a rodent model of parkinson's disease and controls. Neuropsychopharmacology (2012) 37:1397-408. doi: $10.1038 / \mathrm{npp} .2011 .325$

79. Holtz NA, Tedford SE, Persons AL, Grasso SA, Napier TC. Pharmacologically distinct pramipexole-mediated akinesia vs. risk-taking in a rat model of Parkinson's disease. Prog Neuro Psychopharmacology Biol Psychiatry (2016) 70:77-84. doi: 10.1016/j.pnpbp.2016.05.004

80. Tremblay M, Silveira MM, Kaur S, Hosking JG, Adams WK, Baunez C, et al. Chronic D 2 / 3 agonist ropinirole treatment increases preference for uncertainty in rats regardless of baseline choice patterns. Eur J Neurosci. (2017) 45:159-66. doi: 10.1111/ejn.13332

81. Cocker PJ, Tremblay M, Kaur S, Winstanley CA. Chronic administration of the dopamine D 2/3 agonist ropinirole invigorates performance of a rodent slot machine task, potentially indicative of less distractible or compulsive-like gambling behaviour. Psychopharmacology (2017) 234:137-53. doi: 10.1007/s00213-016-4447-y

82. Lee J-Y, Lee EK, Park SS, Lim J-Y, Kim HJ, Kim JS, et al. Association of DRD3 and GRIN2B with impulse control and related behaviors in Parkinson's disease. Mov Disord. (2009) 24:1803-10. doi: 10.1002/mds.22678

83. Leeman RF, Potenza MN. A targeted review of the neurobiology and genetics of behavioural addictions: an emerging area of research. Can J Psychiatry (2013) 58:260-73. doi: 10.1177/070674371305800503

84. Vorel SR, Ashby CR, Paul M, Liu X, Hayes R, Hagan JJ, et al. Dopamine D3 receptor antagonism inhibits cocaine-seeking and cocaine-enhanced brain reward in rats. J Neurosci. (2002) 22:9595-603. doi: 10.1523/JNEUROSCI.22-21-09595.2002

85. Khaled MA, Farid Araki K, Li B, Coen KM, Marinelli PW, Varga J, et al. The selective dopamine D3 receptor antagonist SB 277011-A, but not the partial agonist BP 897, blocks cue-induced reinstatement of nicotine-seeking. Int J Neuropsychopharmacol. (2010) 13:181-90. doi: 10.1017/S1461145709991064

86. Xi Z-X, Gardner EL. Pharmacological actions of NGB 2904, a selective dopamine D3 receptor antagonist, in animal models of drug addiction. CNS Drug Rev. (2007) 13:240-59. doi: 10.1111/j.1527-3458.2007.00013.x

87. Nutt DJ, Lingford-Hughes A, Erritzoe D, Stokes PRA. The dopamine theory of addiction: 40 years of highs and lows. Nat Rev Neurosci. (2015) 16:305-12. doi: 10.1038/nrn3939

88. Volkow ND, Chang L, Wang GJ, Fowler JS, Ding YS, Sedler M, et al. Low level of brain dopamine D2receptors in methamphetamine abusers: association with metabolism in the orbitofrontal cortex. Am J Psychiatry (2001) 158:201521. doi: 10.1176/appi.ajp.158.12.2015

89. Raz N, Rodrigue KM, Kennedy KM, Head D, Gunning-dixon F, Acker JD. Differential aging of the human striatum: longitudinal evidence. Am J Neuroradiol. (2003) 24:1849-56.

90. Ray N, Miyasaki J, Zurowski M, Ko J, Cho S, Pellecchia G, et al. Extrastriatal dopaminergic abnormalities of DA homeostasis in Parkinson's patients with medication-induced pathological gambling: a [11C] FLB-457 and PET study. Neurobiol Dis. (2012) 48:519-25. doi: 10.1016/j.clinph.2011.06.006.A

91. Buckholtz JW, Treadway MT, Cowan RL, Woodward ND, Li R, Ansari MS, et al. Dopaminergic network differences in human impulsivity. Science (2010) 329:532. doi: 10.1126/science. 1185778

92. Lee JY, Jeon BS, Kim HJ, Park SS. Genetic variant of HTR2A associates with risk of impulse control and repetitive behaviors in Parkinson's disease. Park Relat Disord. (2012) 18:76-8. doi: 10.1016/j.parkreldis.2011.08.009

93. Martini A, Dal Lago D, Edelstyn NMJ, Grange JA, Tamburin S. Impulse control disorder in Parkinson's disease: a meta-analysis of cognitive, affective and motivational correlates. Front Neurol. (2018) 9:654. doi: 10.3389/fneur.2018.00654

Conflict of Interest Statement: The authors declare that the research was conducted in the absence of any commercial or financial relationships that could be construed as a potential conflict of interest.

Copyright (c) 2018 Martini, Dal Lago, Edelstyn, Salgarello, Lugoboni and Tamburin. This is an open-access article distributed under the terms of the Creative Commons Attribution License (CC BY). The use, distribution or reproduction in other forums is permitted, provided the original author(s) and the copyright owner(s) are credited and that the original publication in this journal is cited, in accordance with accepted academic practice. No use, distribution or reproduction is permitted which does not comply with these terms. 